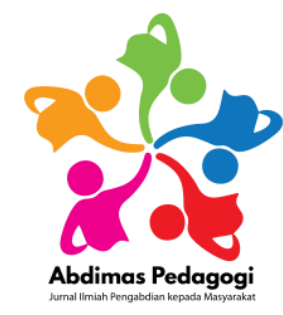

Abdimas Pedagogi: Jurnal Ilmiah Pengabdian kepada Masyarakat

Vol 3, No. 1, 2020, hlm.32-39

ISSN 2615-3122 (online)

ISSN 2548-6683 (print)

\title{
PELATIHAN PEMBUATAN ALAT PERMAINAN EDUKATIF (APE) BERBAHAN LIMBAH RUMAH TANGGA BAGI PENDIDIK PAUD TERINTEGRASI POSYANDU
}

\author{
Ellyn Sugeng Desyanty*1, Sri Wahyuni ${ }^{1}$, Wuri Astutik ${ }^{2}$, Rezka Arina Rahma ${ }^{1}$ \\ ${ }^{1}$ Jurusan Pendidikan Luar Sekolah, Fakultas Ilmu Pendidikan, Universitas Negeri Malang, Indonesia \\ ${ }^{2}$ Jurusan KSDP, Fakultas Ilmu Pendidikan, Universitas Negeri Malang, Indonesia \\ Jalan Semarang No. 5 Malang, Jawa Timur, Indonesia \\ *e-mail: ellynsugeng@fip.um.ac.id
}

artikel masuk: 27 Januari 2020; artikel diterima:30 April 2020

\begin{abstract}
One of the problems that arise in PAUD Post Educators is that one of them is competence in developing Educational Game Tools by utilizing the materials around them. This dedication activity aims to improve the competence of PAUD Post PAUD educators who are focused on the abilities and skills of educators in designing and making educational tools based on multiple intelligence for early childhood learning by utilizing appropriate household waste. The development of educational games (APE) by utilizing household waste that is suitable for use will be able to minimize costs incurred by educational institutions in organizing early childhood learning. The evaluation results show that the material is in accordance with the learning needs of the trainees and the final results of the training are as expected, this can be seen from the results of the evaluation that has been carried out during the training process.
\end{abstract}

Keywords: APE; household waste; multiple intelligences

\begin{abstract}
Abstrak: Permasalahan yang muncul pada pendidik Pos PAUD salah satunya adalah kompetensi dalam mengembangkan Alat Permainan Edukatif dengan memanfaatkan bahan yang ada disekitarnya. Kegiatan pengabdian ini bertujuan untuk meningkatkan kompetensi pendidik Pos PAUD yang difokuskan pada kemampuan dan keterampilan pendidik dalam merancang dan membuat alat permainan edukatif berbasis kecerdasan majemuk untuk pembelajaran anak usia dini dengan memanfaatkan limbah rumah tangga yang layak pakai. Pengembangan alat permaianan edukatif (APE) dengan memanfaatkan limbah rumah tangga yang layak pakai akan dapat meminimalkan biaya yang harus dikeluarkan oleh lembaga pendidikan dalam penyelenggaraan pembelajaran anak usia dini. Hasil evaluasi menunjukkan bahwa materi sesuai dengan kebutuhan belajar para peserta pelatihan dan hasil akhir pelatihan sesuai dengan yang diharapkan, hal ini dapat dilihat dari hasil evaluasi yang telah dilakukan selama proses pelatihan berlangsung.
\end{abstract}

Kata kunci: APE; limbah rumah tangga; kecerdasan majemuk 


\section{PENDAHULUAN}

Kecamatan Dau merupakan salah satu kecamatan dari 33 (tiga puluh tiga) kecamatan yang dimiliki oleh kabupaten Malang. Adapun batas-batas wilayah kecamatan Dau pada sebelah utara adalah kota Batu dan kecamatan Karangploso, berbatasan dengan kota Malang pada sebelah timur, berbatasan dengan kecamatan Wagir pada sebelah selatan, dan kota Batu pada sebelah barat. Kecamatan Dau memiliki luas kawasan sekitar 1,41\% dari total wilayah kabupaten Malang yanitu sekitar 41,96 km2. Kecamatan Dau memiliki 10 desa yang terletak diantara perbukitan dan hutan dengan jumlah penduduk 67.455 jiwa yang terdiri dari 33.497 jiwa penduduk perempuan dan 33.958 jiwa penduduk laki-laki dengan kepadatan penduduk 1.608 jiwa/km2 (BPS, 2018).

Data yang didapatkan oleh tim pengabdian kepada masyarakat kecamatan Dau memiliki fasilitas pendidikan yang relatif lengkap mulai dari PAUD, SD, SMP, dan SMA. Kecamatan Dau memiliki lembaga pendidikan yang keberadaannya tidak hanya didukung oleh pemerintah daerah namun juga didukung oleh masyarakat sekitar. Hasil wawancara tim pengabdian kepada masyarakat didapatkan bahwa Kecamatan Dau memiliki 24 Pos PAUD yaitu lembaga PAUD yang terintegrasi dengan Posyandu. Pos PAUD merupakan bentuk layanan PAUD yang penyelenggaraannya dapat terintegrasi dengan layanan Bina Keluarga Balita (BKB) dan/atau posyandu bagi anak sejak lahir sampai dengan usia 4 (empat) tahun. Pos PAUD merupakan salah satu model PAUD yang dikembangkan melalui pendekatan holistik-integratif yang setidaknya menekankan aspek pendidikan, kesehatan, gizi, perawatan, pengasuhan, kesejahteraan, dan perlindungan. Pos PAUD termasuk dalam pendidikan non formal berbentuk SPS (Satuan PAUD Sejenis) yang berada di bawah Direktorat PAUD.

Selama ini posyandu dalam memberikan layanan kepada anak (balita) fokus pada upaya perbaikan gizi dan layanan kesehatan dasar untuk kelangsungan hidup, dengan kehadiran Pos PAUD program posyandu dapat dilengkapi dengan kegiatan pendidikan. Kecamatan Dau sudah memiliki kegiatan Pos PAUD yang berbasis masyarakat yaitu dilakukan oleh masyarakat, dan untuk masyarakat, sehingga sebagai mitra pemerintah masyarakat memiliki kesempatan yang seluas-luasnya untuk berperan serta dalam memajukan pendidikan Indonesia. Dewantara (1977) menyatakan bahwa pendidikan merupakan tanggung jawab bersama antara keluarga, sekolah, dan masyarakat, sehingga memang pendidikan tidak hanya menjadi tangung jawab salah satu pihak saja melainkan tanggung jawab bersama antar seluruh komponen masyarakat yang ada.

Pendidikan akan berhasil dengan baik bilamana didukung dengan kompetensi pendukung penyelenggaraan pendidikan, misalnya pendidik, fasilitas belajar, serta bahan ajar yang akan digunakan dalam kegiatan pembelajaran. Temuan di lapangan ditemukan bahwa beberapa Pos PAUD memiliki tenaga pendidik dengan latar belakang pendidikan yang bervariasi, beberapa diantaranya lulusan Sekolah Menengah Atas (SMA) atau lulusan S1 non Kependidikan dan Keguruan. Hal tersebut bisa menjadi salah satu penghambat dalam memenuhi kewajibannya menjadi pendidik anak usia dini secara profesional.

Pendidik PAUD sebagai tenaga pendidik anak usia dini yang profesional memiliki tugas untuk memfasilitasi kegiatan pembelajaran anak usia dini dalam mendampingi pertumbuhan kecerdasan majemuk yang telah dimiliki sejak lahir. Gardner menyatakan bahwa kecerdasan kemampuan seseorang untuk memecahkan persoalan yang nyata dan dalam situasi yang bermacam-macam sehingga seseorang yang memiliki kecerdasan tinggi bilaman dia mampu untuk menyelesaikan persoalan hidup yang nyata bukan hanya dalam teori (Chatib, 2010). Kecerdasan merupakan salah satu faktor yang dapat menentukan keberhasilan seseorang dalam keberhasilannya menyelesaikan permasalahan hidup yang muncul dalam dirinya. Atas dasar itulah 
pembelajaran pada anak usia dini harus memperhatikan kecerdasan majemuk yang telah mereka miliki. Pembelajaran harus mampu memfasilitasi perkembangan berbagai kecerdasan tersebut.

Penyediaan alat permainan edukatif (APE) adalah salah satu komponen dalam pembelajaran anak usia dini yang harus dipenuhi dalam rangka mencapai tujuan pembelajaran. Alat permainana edukatif merupakan alat permainan yang sengaja dirancang secara khusus untuk kepentingan pendidikan (Sugianto, 1995). Tidak semua alat permainan yang dimiliki oleh anak usia dini pada saat ini dirancang secara khusus untuk mengembangan aspek-aspek perkembangan dan kecerdasan majemuk anak usia dini. Keberadaan alat permainan edukatif menjadi hal yang diperlukan dalam kegiatan pembelajaran anak usia dini sehingga pencapaian tujuan pembelajaran dapat dilakukan dengan efektif dan efisien. Alat permainan edukatif meminimalisir pengeluaran biaya dengan memanfaatkan limbah rumah tangga yang mudah di dapat dan terjangkau misalnya botol plastik dan lain-lain.

Peningkatan kompetensi pendidik PAUD dalam menunjang kegiatan pembelajaran harus selalu dilakukan baik dalam hal perencanaan pembelajaran, pelaksanaan pembelajaran, serta evaluasi pembelajaran anak usia dini. Dari hasil pengamatan tim pengabdian kepada masyarakat diketahui bahwa tidak semua pendidik PAUD yang dalam hal ini adalah pendidik PAUD yang terintegrasi dengan posyandu memahami dan memiliki keterampilan untuk merancang serta mengembangkan alat permainan edukatif yang sesuai dengan potensi kcerdasan jamak anak usia dini. Pos PAUD masih banyak memanfatkan alat permainan edukatif yang tersedia dipasaran (membeli) sehingga memunculkan persoalan baru yaitu: (1) tidak semua alat permainan edukatif yang tersedia di pasar sengaja dirancang untuk tujuan pembelajaran, (2) penyediaan alat permainan edukatif sangat bergantung pada ketersediaan biaya operasional, (3) alat permainan edukatif yang dibeli belum bisa dimanfaatkan oleh seluruh peserta belajar karena keterbatasan jumlah.

\section{METODE}

Metode yang dipilih oleh tim pengabdian kepada masyarakat adalah melalui pelatihan yangmana pelatihan sebagai usaha sistematis untuk menguasai keterampilan, peraturan, konsep, atau cara berperilaku yang berdampak pada peningkatan kinerja (Kamil, 2010). Pelatihan pembuatan APE berbasis kecerdasan majemuk berbahan limbah rumah tangga memiliki tujuan untuk meningkatkan kompetensi bagi pendidik PAUD yang terintegrasi dengan posyandu. Dearden dalam Kamil (2010) menyatakan bahwa pelatihan meliputi proses belajar mengajar bertujuan untuk mencapa tingkatan kompetensi tertentu atau efisiensi kerja. Moekijat (1992) meyebutkan bahwa tujuan pelatihan adalah untuk (1) mengembangkan keahlian sehingga pekerjaan dapat diselesaikan dengan lebih cepat dan efektif, (2) mengembangkan pengetahuan sehingga pekerjaan dapat dikerjakan secara rasional, dan (3) mengembangkan sikap sehingga menimbulkan kemampuan kerjasama antar pegawai serta dengan pimpinan.

Kegiatan pengabdian kepada pendidik yang masyarakat telah dilakukan dengan model pembelajaran andragogi partisipatif dengan tujuan untuk mengajak setiap sasaran belajar berpartisipasi secara aktif selama kegiatan berlangsung. Andragogi secara teoritis mempunyai empat asumsi dasar, yaitu: (1) sellf directedness (kemampuan mengarahkan diri sendiri), (2) pengalaman belajar, (3) kesiapan belajar berdasarkan kebutuhan, dan (4) memiliki orientasi belajar (Zaini, et al 2002). Metode pelatihan tersebut antara lain: (1) ceramah dan tanya jawab untuk menyampaikan materi yang bersifat konseptual, materi pemahaman dan pengenalan tentang pembelajaran PAUD berbasis kecerdasan jamak, serta hakikat alat permainan edukatif bagi anak usia dini; (2) praktek langsung, untuk menyampaikan materi tentang pembuatan alat permainan edukatif berbasis kecerdasan jamak dengan memanfaatkan bahan limbah rumah tangga; (3) 
pemberian tugas secara berkelompok untuk proses pembuatan alat permainan edukatif berbasis kecerdasan jamak, pada setiap kelompok akan membuat seperangkat alat permainan edukatif sesuai dengan salah satu kecerdasan dari kecerdasan jamak; (4) presentasi untuk mempresentasikan hasil tugas masing-masing kelompok sehingga kelompok yang lain bisa memberikan tanggapan dan komentar; (5) diskusi untuk melakukan evaluasi dan umpan balik tentang proses dan hasil kegiatan pengabdian kepada masyarakat.

\section{HASIL DAN PEMBAHASAN}

Kegiatan pengabdian kepada masyarakat ini diselenggarakan dengan bermitra dengan HIMPAUDI Kecamatan Dau Kabupaten Malang. Kegiatan bertujuan untuk mengingkatkan pemahaman para pendidik PAUD di Kecamatan Dau Kabupaten Malang tentang pemanfaatan limbah rumah tangga sebagai Alat Permainan Edukatif (APE) serta mampu mempraktekkan bagaimana pembuatan APE dengan memanfaatkan bahan limbah rumah tangga. Pelatihan diikuti oleh 50 orang pendidik PAUD yang tergabung dalam HIMPAUDI Kecamatan Dau Kabupaten Malang.

Kegiatan pelatihan dilaksanakan selama dua hari yaitu pada tanggal 6 - 7 Juli 2019 bertempat di Kecamatan Dau Kabupaten Malang. Kegiatan pada hari pertama adalah penyampaian materi tentang (1) Konsep Dasar Pembelajaran Anak Usia Dini, (2) Kecerdasan Majemuk Pada Anak Usia Dini, dan (3) Peran Alat Permainan Edukatif dalam Pembelajaran Anak Usia Dini. Pada hari kedua praktek Pembuatan APE berbahan Limbah Rumah Tangga serta presentasi hasil praktek yang dilakukan oleh peserta pelatihan.

Secara umum proses pelatihan dimulai dengan pengisian buku kehadiran peserta sebagaimana terlihat pada gambar 1 dengan maksud untuk melakukan cek terhadap kehadiran peserta yang telah diundang. Kegiatan pembukaan dimulai dengan tepat waktu, pada kegiaan pendahuluan ketua tim menyampaikan tentang maksud dan tujuan dari pelaksanaan program pengabdian kepada masyarakat. Selanjutnya sambutan dari lembaga mitra dan perwakilan dari penilik TK Kecamatan Dau sekaligus membuka kegiatan.

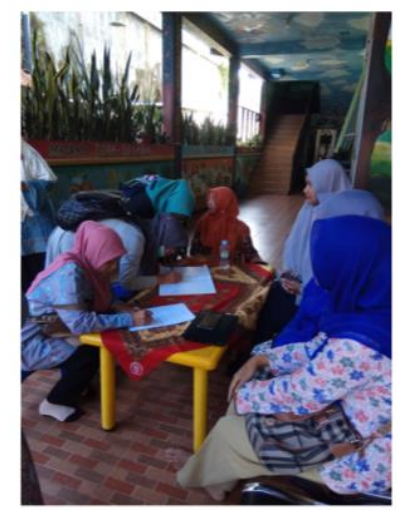

\section{Gambar 1. Proses peserta mengisi buku kehadiran dalam kegiatan pelatihan}

Penyajian materi pelatihan dilakukan melalui ceramah, tanya jawab, praktek pembuatan APE, dan presentasi hasil yang telah dibuat oleh peserta pelatihan. Materi pelatihan terdiri dari 4 sesi yang dipandu oleh narasumber dan mahasiswa S2 PLS Universitas Negeri Malang. Pihak yang dilibatkan dalam kegiatan ini adalah pelaksana pengabdian kepada masyarakat, yaitu: (1) Rezka Arina Rahma, S.Pd., M.Pd yang menyampaikan materi tentang Pembelajaran pada Anak Usia Dini; (2) Dr. Ellyn Sugeng Desyanty, S.Pd., M.Pd yang menyampaikan materi tentang Kecerdasan Majemuk pada Anak Usia Dini; (3) Wuri Astutik, S.Pd., M.Pd yang menyampaikan 
materi tentang APE dan memandu jalannya praktek pemanfaatan limbah rumah tangga menjadi APE; dan (4) mahasiswa S2 PLS.

Penyajian materi pelatihan yang terdiri dari dua hari dengan berbagai materi dirancang dengan menggunakan metode ceramah dan praktek secara langsung. Penyampaian materi secara ceramah dan tanya jawab disampaikan pada tiga materi yaitu: (1) Pembelajaran Anak Usia Dini, (2) Kecerdasan Majemuk Pada Anak Usia Dini, dan (3) Peran Alat Permainan Edukatif dalam Pembelajaran Anak Usia Dini.

Penyajian materi pada hari kedua menggunakan metode praktek pada materi Pembuatan APE berbahan Limbah Rumah Tangga sebagaimana ditampilkan pada gambar 2. Setelah melaksanakan praktek para peserta secara berkelompok melakukan presentasi hasil APE yang telah disusun sebagaimana terlihat pada gambar 3. Peserta pelatihan dibagi menjadi delapan kelompok dan diminta untuk mengembangkan APE serta membuat sebuah presentasi tentang APE yang telah dikembangkan bersama. Pada saat presentasi kelompok berlangsung fasilitator akan memberikan pendapat serta masukan terhadap APE yang telah dikembangkan oleh kelompok (gambar 4).

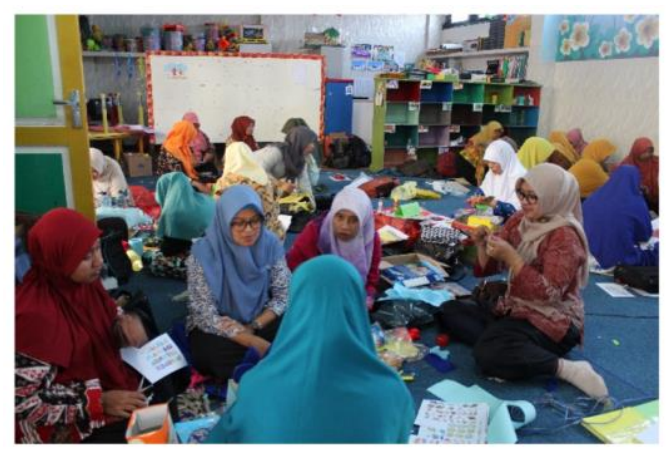

Gambar 2. Peserta melakukan praktek pembuatan APE

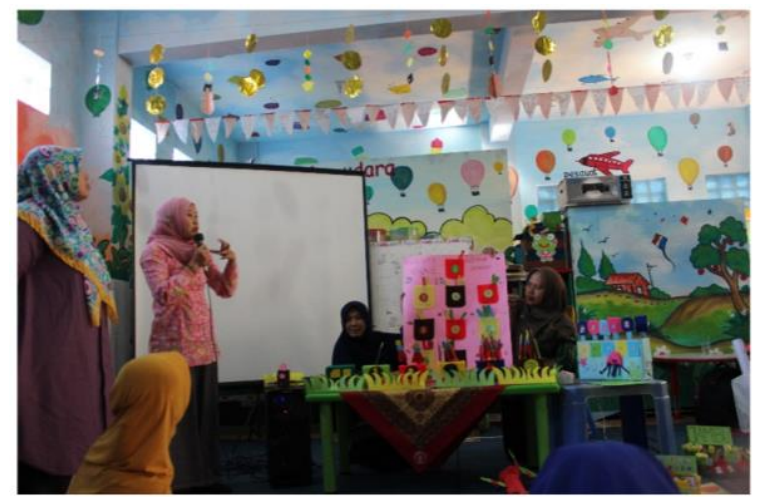

Gambar 3. Peserta mempresentasikan APE yang telah berhasil dibuat secara berkelompok

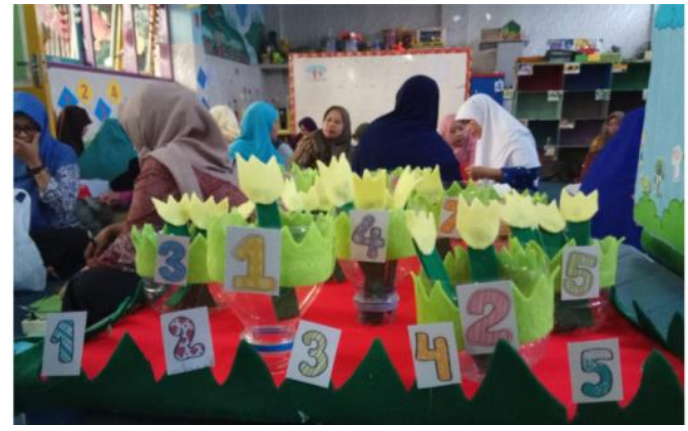

Gambar 4. APE yang telah dikembangkan peserta 
Sesi terakhir kegiatan pelatihan adalah antara tim pengabdian kepada masyarakat dan peserta pelatihan berdiskusi tentang rencana tindak lanjut yang akan dilakukan oleh peserta setelah kegiatan berakhir serta pengisian evaluasi kegiatan pelatihan.

Selanjutnya akan kami sajikan hasil analisis tentang evaluasi kegiatan dari beberapa indikator yang telah kami tentukan sebelumnya yaitu: (1) indikator tentang kesesuaian materi dengan tujuan penelitian dapat dilihat pada grafik pada gambar 5 yang menjelaskan bahwa $80 \%$ peserta menyatakan bahwa materi sangat sesuai dengan tujuan pelatihan yang telah ditetapkan, hal ini disebabkan tujuan pelatihan sejak awal memang telah disepakati oleh peserta bersama dengan tim pengabdian kepada masyarakat; (2) kesesuaian materi dengan kebutuhan, gambar 6 menunjukkan bahwa $85 \%$ peserta menyatakan bahwa materi sangat sesuai dengan kebutuhan peserta pelatihan dan $15 \%$ peserta menyatakan materi sesuai dengan kebutuhan peserta pelatihan dan hal ini disebabkan karena materi disesuaikan dengan hasil observasi yang telah dilakukan pada sebelum kegiatan dilaksanakan; (3) kreativitas peserta dilihat dari produk pelatihan, pada gambar 7 terlihat bahwa $84 \%$ narasumber menyatakan bahwa produk APE yang dihasilkan oleh peserta pelatihan sangat kreatif dalam aspek pengembangan APE dengan memanfaatkan bahan limbah rumah tangga; (4) penampilan, gambar 8 tersebut menyatakan bahwa $86 \%$ narasumber menyatakan bahwa produk APE berbahan limbah rumah tangga yang dihasilkan oleh peserta pelatihan sangat baik pada aspek keindahan pengembangan APE.

\section{Kesesuaian materi dengan tujuan pelatihan}

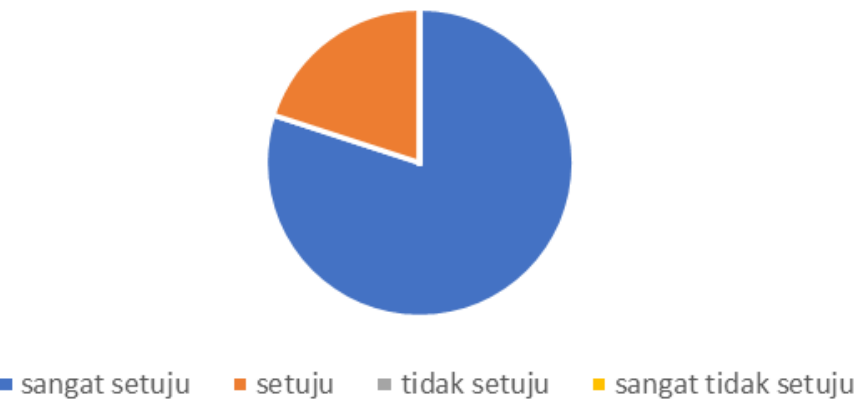

\section{Gambar 5. Diagram kesesuaian materi dengan tujuan pelatihan}

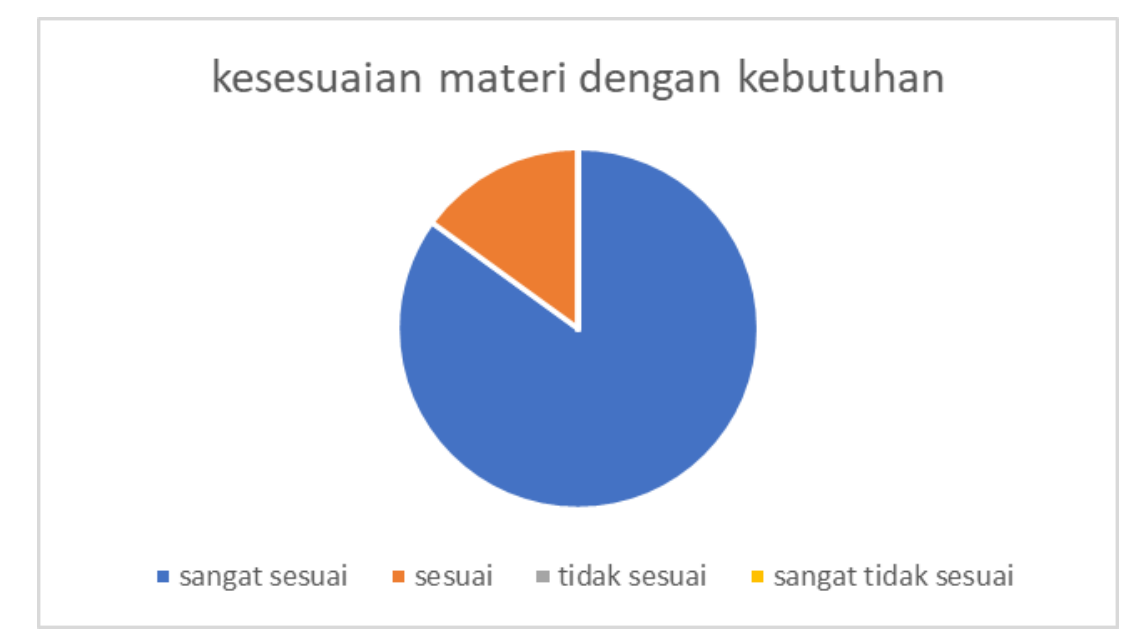

Gambar 6. Diagram kesesuaian materi dengan kebutuhan 


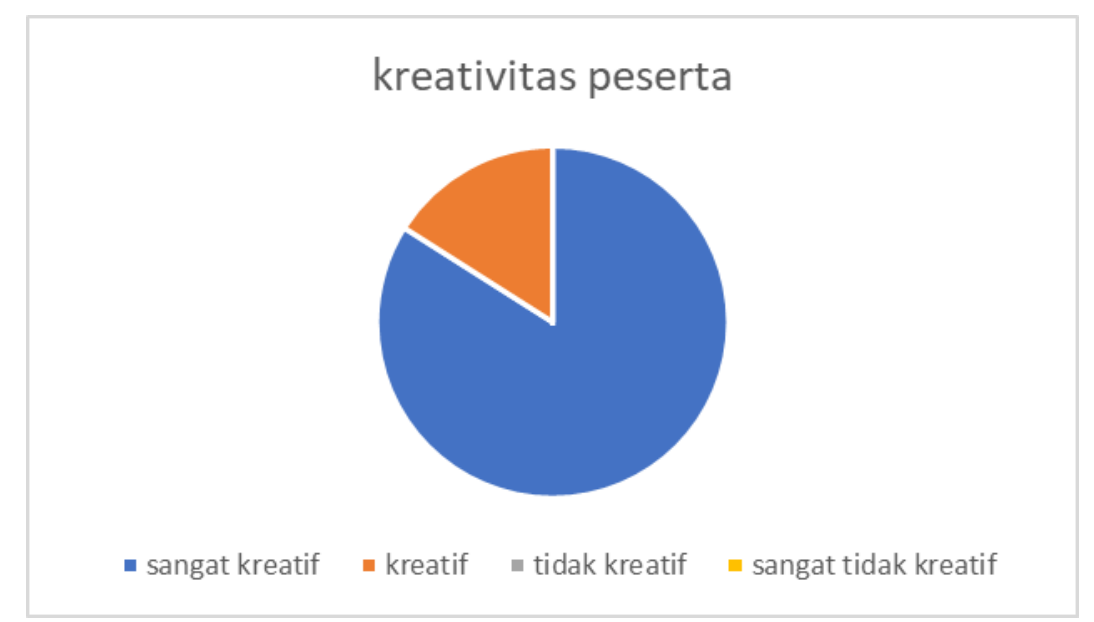

\section{Gambar 7. Diagram kreativitas peserta}

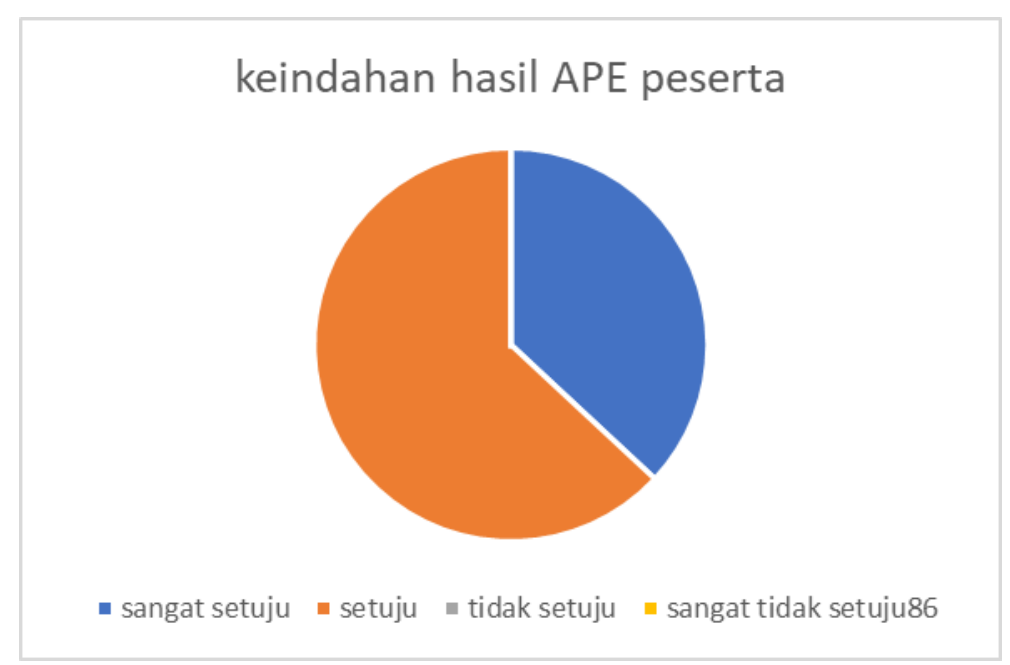

\section{Gambar 8. Diagram keindahan hasil APE peserta}

Berdasarkan data dan informasi yang telah dikumpulkan oleh tim pengabdian dapat disimpulkan bahwa para peserta pelatihan sangat puas terhadap pelaksanaan pelatihan dan produk APE yang dihasilkan oleh peserta pelatihan sudah mencapai hasil yang diharapkan dalam tujuan pelatihan. Pelatihan berbasis praktek pada orang dewasa terbukti mampu membantu peserta dalam menambah pengetahuan dan keterampilannya sebagaimana Knowles, Holton, dan Swanson (1998) menyatakan bahwa orang dewasa membutuhkan proses pembelajaran yang didasari oleh prinsipprinsip pembelajaran orang dewasa yang sudah memiliki banyak pengalaman yang dapat digunakan sebagai dasar aktivitas dalam kegiatan pembelajaran.

\section{SIMPULAN}

Kegiatan pelatihan sebagai wujud kerja dari pengabdian kepada masyarakat yang telah dilaksanakan oleh tim pengabdian kepada masyarakat berjalan dengan baik dan sesuai dengan dan lancar yang dibuktikan dengan hasil evaluasi yang sesuai dengan yang diharapkan pada tujuan kegiatan.

Hasil evaluasi menunjukkan bahwa materi sesuai dengan kebutuhan belajar para peserta pelatihan dan hasil akhir pelatihan sesuai dengan yang diharapkan. Kegiatan pengabdian yang akan datang bisa dilakukan pelatihan yang sejenis dengan jumlah peserta yang lebih banyak dan jangkauan daerah yang lebih luas sehingga pendidik PAUD terintegrasi posyandu mampu 
memanfaatkan benda yang ada disekitarnya sebagai alat permainan edukatif bagi anak usia dini dalam pembelajaran.

\section{DAFTAR RUJUKAN}

Chatib, M. (2010). Sekolahnya Manusia Sekolah Berbasis Miltiple Intelligence di Indonesia. Bandung: Kaifa.

Dewantara, K. H. (1977). Karya Ki Hadjar Dewantara. Yogyakarta: Majelis Persatuan Taman Siswa.

Knowles, M., Holton, E., \& Swanson, R. (1998). The Adult Learner: The Definitive Classic in Adult Education and Human Resources Development. Houston: Gulf Publishing Company.

Sugianto, M. (1995). Bermain, Mainan, dan Permainan. Jakarta; Depsikbud Dirjen Dikti.

Sujiono, Y. N. (2011). Konsep Dasar Pendidikan Anak Usia Dini. Jakarta: PT. Indeks.

Suyadi. (2010). Psikologi Belajar Anak Usia Dini. Yogyakarta: PEDAGOGIA 